\title{
Autonomiczna Republika Krymu: pogranicze ukraińsko-rosyjskie
}

\author{
Bożena Wroniszewska ${ }^{1}$
}

\begin{abstract}
:
The present article is the category of the Ukrainian-Russian border area with particular attention to the Autonomous Republic of Crimea. It is important to show the border in different contexts and facts. In the first part of the article reference is made to the events that unfolded on the territory of Ukraine at the end of 2013 and the first months of 2014. These events clearly show that the South East of Ukraine is not a monolith. Otherwise society works Crimea, Donbass otherwise, and even otherwise Odessa and Kharkov. In the second part of the article author outlines the history of the Crimean Tatars ethnos, which proved to be indispensable to show that the people belonging to the Autonomous Republic of Crimea. Reference was made also to the current situation of the Crimean Tatars. In the third part analyzed the Ukrainian-Russian border. Mainly characterized the maritime border, which is an important part between Russia and Ukraine. Describes in detail the essence of the dispute between the Russian Federation and Ukraine on the island of Tuzla.
\end{abstract}

Keywords:

borderland, Autonomous Republic of Crimea, Ukraine, Russia, conflict, revolution, Crimean Tatars

\section{Streszczenie:}

Przedmiotem niniejszego artykułu jest kategoria pogranicza ukraińsko-rosyjskiego ze szczególnym uwzględnieniem Autonomicznej Republiki Krymu. Istotne jest ukazanie pogranicza w różnych kontekstach i ujęciach, dlatego w pierwszej części artykułu odniesiono się do wydarzeń, jakie rozgrywały się na terytorium Ukrainy na końcu 2013 roku i w pierwszych miesiącach 2014 roku. Wydarzenia ostatnich miesięcy pokazuja wyraźnie, że Południowy Wschód Ukrainy nie jest monolitem. Inaczej funkcjonuje społeczeństwo Krymu, inaczej Donbasu, a jeszcze inaczej Odessy czy Charkowa. W drugiej części artykułu przedstawiono zarys historyczny etnosu Tatarów krymskich, który okazał się niezbędny do ukazania przynależności tego narodu do Autonomicznej Republiki Krymu. Odniesiono się również do obecnej sytuacji Tatarów krymskich na Krymie. W trzeciej części poddano analizie granicę ukraińsko-rosyjską. W głównej mierze scharakteryzowano granicę morską, która jest ważna częścią między Rosją i Ukrainą. Szczegótowo opisano istotę sporu między Federacją Rosyjską a Ukraina w kwestii wyspy Tuzła, będącej „częściq̨” Półwyspu Tamańskiego.

Słowa kluczowe:

pogranicze, Autonomiczna Republika Krymu, Ukraina, Rosja, konflikt, rewolucja, Tatarzy Krymscy

Link do artykułu:

http://pogranicze.uni.opole.pl/biblioteka/docs/tom2/wroniszewska_t2n1.pdf

Standard cytowania (APA):

Wroniszewska, B. (2014). Autonomiczna Republika Krymu - pogranicze ukraińskorosyjskie. Pogranicze. Polish Borderlands Studies, t. 2, nr 1, s. 100-112.

\section{Wprowadzenie}

Nie sposób w pełni oddać realiów Ukrainy z czasu wydarzeń, jakie rozgrywały się na terytorium tego państwa na końcu 2013 roku i w pierwszych miesiącach 2014 roku. Sukces Majdanu był spełnieniem nadziei znacznej części społeczeństwa ukraińskiego i poniekąd przyrzeczeniem ze strony nowych liderów przeprowadzenia reform, które miały uzdrowić sytuację polityczną i społeczno-gospodarczą. Zakrawa to na ironię losu,

\footnotetext{
1 Mgr Bożena Wroniszewska - doktorantka w Instytucie Politologii Uniwersytetu Opolskiego.
} 
albowiem na przełomie 2004/2005 roku - podczas Pomarańczowej Rewolucji - Ukraina stanęła przed podobnym wyborem kierunku ewolucji jej systemu politycznego po dekadzie rządów Leonida Kuczmy. Teraz pojawiła się szansa na przełom po rządach Wiktora Janukowycza. Niezaprzeczalnym sukcesem Pomarańczowej Rewolucji było powstrzymanie realnie rysującego się procesu „degeneracji” systemu w kierunku autokratyzmu. W czasie, gdy zdominowana przez opozycję Rada Najwyższa w lutym 2014 roku przyjmowała historyczne uchwały, południowo-wschodnia część Ukrainy ciążyła w stronę Rosji, choć wydarzenia ostatnich miesięcy pokazują wyraźnie, że tzw. Południowy Wschód Ukrainy nie jest monolitem, bowiem inaczej funkcjonuje społeczeństwo Krymu, inaczej Donbasu, a jeszcze inaczej Charkowa i Odessy etc. Początkowo wydawało się, że dążenie do ustabilizowania demokratycznych struktur państwa powinno sprzyjać umocnieniu nadal relatywnie słabego poczucia tożsamości narodowej, ale ocena obiektywnych przesłanek trwałości „państwa narodowego” okazała się być nieadekwatna do rzeczywistości. Różnice między najbardziej na zachód wysuniętymi połaciami Galicji a Donbasem i Krymem z każdym dniem narastały (Baluk 2002: 245). Do tej pory opozycję łączyło jedno hasło: „Janukowycz musi odejść". W marcu 2014 roku straciło ono na znaczeniu i nawet w atmosferze patosu i patriotycznej euforii, jaka zapanowała na Majdanie, dało się dostrzec, że wraz poczuciem zwycięstwa odżyły ostre podziały. W lutym 2014 roku prorosyjska organizacja Front Ukraiński z pomocą gubernatora obwodu donieckiego Michaiła Dobkina zorganizowała zjazd deputowanych i przedstawicieli władz lokalnych z południowo-wschodniej części kraju. Do Charkowa przybyło około czterech tysięcy delegatów z Doniecka, Ługańska, Dniepropietrowska, a także z Sewastopola i Krymu. Delegaci zjazdu ogłosili mobilizację w regionie oraz zgłosili swoiste wotum nieufności Radzie Najwyższej, która ich zdaniem złamała prawo i konstytucję. Zdaniem dyrektora kijowskiego Instytutu Polityki Ukraińskiej, Konstantina Bondarenki, mieszkańcy wschodniej części Ukrainy sprzeciwili się bezprawiu, które według nich dokonało się w Kijowie. Za podstawę uznali m.in. likwidację ustawy językowej, która podnosiła rangę języka rosyjskiego, czyniąc go oficjalnym językiem regionalnym na połowie terytorium kraju. Uważali, że Parlament w Kijowie w jednej z pierwszych ustaw pogwałcił konwencje międzynarodowe dotyczące prawa do posługiwania się językiem ojczystym przez ludność rosyjskojęzyczną (Soszyn 2014a: 8). W narastającym konflikcie Rada Najwyższa Ukrainy 27 lutego unieważniła postanowienie w sprawie amnestii oraz przyjęła ustawę o rehabilitacji więźniów politycznych (Giziński 2014: 7).

\section{Tatarzy krymscy i Rosjanie - historia i język}

Nie są wyjaśnione jednoznacznie polityczne początki Chanatu Krymskiego. Selim Chazbijewicz podaje rok 1449 jako datę osadzenia na tronie krymskim Hadżi Gereja. Kolejni władcy stopniowo podporządkowali sobie stepy nadczarnomorskie, stając się suwerenami obszaru pomiędzy deltą Dunaju, wybrzeżem Morza Azowskiego na wschodzie i północnym przedgórzem Kaukazu (Podhordecki 1987: 13). W 1475 roku, w wyniku zajęcia przez Turków osmańskich południowego Krymu, przyjęto zwierzchnictwo imperium osmańskiego. Natomiast w 1770 roku w wyniku podpisania traktatu w Küczük Kajnardży, region uzyskał niezależność wobec Turcji, pozostając protektoratem Rosji. Po przyłączeniu Krymu do Rosji na Tatarów krymskich spadły represje oraz rozpoczął się proces masowych wysiedleń. Polityka Rosji ukierunkowana była na całkowite przesiedlenie i pozbycie się ludności tatarskiej, co miało ułatwić ekspansję. Realizowano wówczas politykę kolonialną, na którą składał się system administracyjnych nakazów i dekretów 
państwowych, które ograniczały tatarski stan posiadania, likwidowały wolności religijne, tradycje, kulturę i rusyfikowały ludność Krymu (Chazbijewicz 2001a: 26-32). Sposób przeprowadzania deportacji powodował, że większa część majątku osób wysiedlonych dostawała się w ręce Rosjan. Na miejsce wysiedlonych Tatarów krymskich osadzano kolonistów rosyjskich, którym oferowano ziemię i majątek zagrabiony wysiedleńcom. Do 1790 roku Półwysep Krymski opuściło około 300 tys. Tatarów. Jeszcze przed aneksją chanatu krymskiego - w okresie formalnej suwerenności - w 1778 roku Rosja doprowadziła do migracji ludności chrześcijańskiej, zasymilowanej z Tatarami, przeważnie zajmującej się handlem i rzemiosłem. Był to poważny cios dla gospodarki i zasobów ludnościowych chanatu. Polityka kolonialna zmuszała również ludność tatarską do emigracji z Krymu do Turcji. Masowy exodus, jak pisze Chazbijewicz, trwał od 1795 do 1902 roku (Chazbijewicz 2001a: 36). Według Edige M. Kirimala w latach 1783-1902 Krym opuściło 1-1,5 mln Tatarów, natomiast liczbę uchodźców szacuje się na 1-1,2 mln (Kirimal 1995: 26). Emigranci tatarscy z Krymu kierowali się w XIX wieku głównie na ziemie państwa osmańskiego, do Dobrudży, Bułgarii i Anatolii. Według Chazbijewicza, największe skupisko powstało w Dobrudży, gdzie niegdyś istniało osadnictwo ord nogajskich po upadku chanatu. Na tym terenie Tatarzy rozwinęli szkolnictwo, literaturę, prasę oraz podtrzymywali tradycje językowe i narodowe. Do dziś można obserwować osadnictwo tatarskie w Bułgarii. Największe straty gospodarcze oraz ludnościowe ponieśli Tatarzy krymscy w latach 1853-1856 podczas wojny krymskiej. Okupacja części terytorium Krymu przyniosła w okręgu Eupatorii grabieże, represje i gwałty ze strony Francuzów, o których głośno mówiło się w Europie. Ludność tatarska wystosowała w tej sprawie memoriał do władz rosyjskich w Symferopolu. Po kilku miesiącach na Krym wkroczyły oddziały kozackie, dońskie, kubańskie i sytuacja powtórzyła się po rosyjskiej stronie frontu. Kozacy palili wsie, gwałcili, oraz rabowali.

Narodowe odrodzenie Tatarów krymskich nastąpiło w II poł. XIX wieku. Utożsamiać je należy z postacią Ismaila Bej Gasprinskiego - twórcy świadomości narodowej Tatarów krymskich. Pod koniec XIX wieku rozwinęly się na Krymie spółdzielnie tatarskie, wzrósł duch solidaryzmu społecznego oraz powstały pierwsze organizacje charytatywne wspomagające głównie działalność szkół, tworząc fundusze stypendialne dla tatarskich uczniów. W północnych częściach Krymu zawiązała się tajna grupa nastawionych rewolucyjnie nauczycieli, określana mianem młodotatarów. Za głównego wroga uznawali państwowy system carskiej Rosji. Postulowali zwrot gruntów 50 tys. bezrolnych chłopów na Krymie. Uczestnicy ruchu młodotatarskiego aktywnie włączyli się w wydarzenia rewolucyjne w 1905 roku. Manifest cara proklamował wolność obywatelską w Cesarstwie Rosyjskim i umożliwił młodotatarom legalną działalność. W tym samym roku na Krymie powołano tajną tatarską organizację „Azm-i-umid” (Wielka Nadzieja).

Podczas I wojny światowej Tatarzy krymscy prowadzili aktywną działalność propagandową w Europie, na rzecz niepodległości bądź autonomii Krymu. Duże znaczenie dla wielonarodowej i wieloreligijnej ludności Krymu miało zniesienie w dobie rewolucji ograniczeń wolności prasy, słowa, religii itd. Postanowieniem Rządu Tymczasowego z 20 marca 1917 roku zadeklarowano równość wszystkich obywateli Rosji. Wówczas pojawił się problem określenia nierosyjskich narodów. W wypadku Tatarów krymskich zniesienie ograniczeń wpłynęło na szybką zmianę postulatu niepodległości narodowej w ramach własnego suwerennego państwa. Według E. Kirimala, dochodzenie do niepodległości odbywało się w trzech fazach: autonomii kulturalnej, walki o autonomię terytorialną oraz w okresie narodowej niepodległości. W 1917 roku przedstawiciele narodowych organizacji 
zorganizowali kongres tatarskiej ludności Krymu w Symferopolu. Na ich czele stał Seytdżeli Hattat. W kongresie uczestniczyły ponad dwa tysiące Tatarów krymskich. W 1920 roku zakończył się etap pełen nadziei dla ludności tatarskiej. Armia Czerwona - 12 listopada przerwała białogwardyjską obronę i wkroczyła na terytorium Krymu. Ewakuowano około 170 tys. ludzi. Uciekali nie tylko cywile, ale również żołnierze i oficerowie armii. Po zajęciu półwyspu przez Armię Czerwoną w ślad za wojskiem weszły odziały CZK, siejąc terror i realizując politykę ludobójstwa (Kirimal 1995: 28-44).

Poprawa warunków życiowych Tatarów krymskich nastąpiła po uregulowaniu statusu Krymu dekretem Wszechrosyjskiego Komitetu Wykonawczego i Rady Komisarzy Ludowych w 1921 roku wraz z realizacją przez Związek Radziecki polityki narodowościowej zwanej polityką korenizacji. Na Krymie przyjęło to formę tataryzacji. Tatarzy krymscy obejmowali stanowiska kierownicze, administracyjne oraz polityczne. W uchwalonej przez Krymską Autonomiczną Socjalistyczną Republikę Radziecką konstytucji zawarto artykuł o języku tatarskim jako drugim języku urzędowym republiki. Dzięki realizacji postanowień nowej polityki narodowościowej nastąpił postęp w rozwoju życia kulturalnego i naukowego Tatarów. Szczególnie wyraźna była poprawa stanu szkolnictwa. Burzliwy rozwój przeżywały: teatr, muzea, biblioteki oraz religia. Zaczęły się również rozwijać środki masowego przekazu. Największy skok nastąpił w wydawaniu prasy tatarskiej. Statystyczne dane dotyczące narodowości ludności Krymu przedstawiały się wówczas następująco: Rosjanie stanowili 51 proc.; Tatarzy krymscy - 25, 9 proc.; Niemcy - 5,9 proc.; Żydzi - 6,9 proc.; Grecy 3,3 proc.; Bułgarzy - 1,6 proc.; Ormianie - 1,7 proc.; Polacy - 0,8 proc.; Karaimi - 0,8 proc.; Estowie - 0,4 proc.; Czesi i Słowacy - 0,2 proc.

W 1922 roku Krym dotknęła klęska głodu, obejmująca także znaczną część Ukrainy i Rosji. Szacuje się, że wskutek głodu na Krymie zmarło około 100 tys. osób, natomiast 50 tys. opuściło te tereny w poszukiwaniu pożywienia. Klęska dotknęła wszystkie grupy etniczne, w znacznym stopniu ludność krymskotatarską. W marcu 1922 roku zmarło 19,9 tys., w kwietniu 12,8 tys. Tatarów. Głód na Krymie osiągnął wówczas rozmiary dotąd niespotykane. W tym okresie Krym utracił około 21 proc. ludności. Ludność miast zmniejszyła się o 23 proc., natomiast ludność wsi o 18 proc. (Chazbijewicz 2001a: 80-110). Kolejna klęska głodu wystąpiła w latach 1931-1933. Odejście od ww. polityki narodowościowej w 1931 roku na rzecz sowietyzacji i rusyfikacji trwało do 1936 roku. Rozpoczął się wtedy kolejny etap wyniszczania Tatarów krymskich. Ludność, w tym także muzułmańscy duchowni zmuszeni zostali do emigracji lub zostali zamordowani. Represjonowano krymskotatarską inteligencję oskarżoną o trockizm i kontrrewolucjonizm. Końcowym etapem rusyfikacji było przyjęcie grażdanki - alfabetu rosyjskiego nieodpowiadającego językowi tatarskiemu. W latach 1937-1938 przeprowadzono kolejną eksterminację ludności krymskotatarskiej. Określa się ją mianem ,jeżowszczyzny”. Chłopi poddani zostali kolektywizacji. Wielu chłopów zginęło (160-170 tys.) lub zostało zesłanych. Pozostali Tatarzy byli dyskryminowani i systematycznie pozbawiani podstawowych praw człowieka i praw obywatelskich (Kirimal 1995: 145-147).

Ponowne wysiedlenie Tatarów krymskich nastąpiło w 1944 roku. Była to sowiecka akcja deportacyjna opracowana i przedstawiona Józefowi Stalinowi przez Ludowego Komisarza Spraw Wewnętrznych ZSRR - Ławrientija Berię. Wydał on rozkaz oczyszczenia Krymu z elementów antysowieckich, uzasadniając ten proces kolaboracją z Niemcami przeciw władzy radzieckiej i zagrożeniem wynikającym $\mathrm{z}$ ich dalszego przebywania na pograniczu. W latach 40-tych XX wieku, w czasie ofensywy i okupacji niemieckiej, 
ludność krymskotatarska we współpracy z Niemcami widziała szansę na zdobycie niepodległości i zmianę systemu politycznego. Władze niemieckie utworzyły wówczas z ochotników krymskotatarskich bataliony samoobrony, chroniące wsie przed atakami partyzantki sowieckiej. W sumie w oddziałach militarnych pod okiem wojsk niemieckich służyło około 20 tys. osób. Z drugiej strony, w szeregach Armii Czerwonej, walczyło ponad 50 tys. Tatarów krymskich. Ławrientij Beria proponował wysiedlenie ludności krymskotatarskiej do Uzbeckiej Socjalistycznej Republiki Radzieckiej. Ostatecznie 11 maja 1944 roku Państwowy Komitet Obrony podjął decyzję o przesiedleniu ludności krymskotatarskiej do Uzbekistanu, Maryjskiej Autonomicznej Socjalistycznej Republiki Radzieckiej oraz obwodu: mołotowskiego, iwanowskiego, gorkowskiego i swierdłowskiego. Akcja wysiedlania kierowana była przez bezpośrednich współpracowników Berii: Bogdana Zacharewicza Kobułowa i Iwana Sierowa. Podobno już w 1941 roku istniał plan przesiedlenia Tatarów krymskich, podobnie jak krymskich Niemców do Kazachstanu. O terminie wysiedlenia informowano w ostatniej chwili, a wywożeni mogli ze sobą zabrać niewielką ilość bagażu, który przy okazji rewidowano i często grabiono. Pierwszego dnia do bydlęcych wagonów załadowano około 90 tys. osób. Ogółem liczbę wysiedlonej ludności krymskotatarskiej ocenia się na około 190 tys. Wysiedlono także około 50 tys. Niemców, następnie Ormian, Turków, Greków, Romów oraz Bułgarów. Po akcji deportacyjnej obowiązywał odgórny zakaz powrotu i osiedlania się ludności krymskotatarskiej na Krymie. Ponadto, około sześciu tysięcy Tatarów krymskich w wieku poborowym zostało skierowanych do Rybińska, Kujbyszewa i Guriewa do dyspozycji wojskowych przedsiębiorstw naftowych, a następnie do dyspozycji trustu węglowego (około pięć tysięcy). Szacuje się, że deportacje przeprowadzone w końcu 1943 i na początku 1944 roku objęły około miliona osób. Zesłani zostali m.in.: Czeczeni, krymscy Grecy, Krymczacy, Bułgarzy. Bałkarów deportowano z Kabardyno-Bałkarii, natomiast Kurdów z Południa Gruzji.

Oprócz masowych wysiedleń Tatarów krymskich popełnione zostały także zbrodnie wobec pozostałej ludności. W lipcu 1944 roku na zlecenie Bogdana Kobułowa zamordowano ludność krymskotatarską pominiętą w toku deportacji. Otoczeni przez żołnierzy Ludowego Komisariatu Spraw Wewnętrznych ZSRR mieszkańcy, zostali załadowani na łodzie i wywiezieni na najgłębszą część Morza Azowskiego. Następnie łodzie zatopiono. Pod koniec 1944 roku władze ZSRR podjęły działania mające na celu zatarcie śladów krymskotatarskiej kultury, a 22 października biuro Komitetu Obwodowego WKP(b) Krymu przyjęło postanowienie o zmianie nazw miejscowych związanych z greckimi, niemieckimi i krymskotatarskimi mieszkańcami. 14 grudnia 1944 roku Prezydium Rady Najwyższej Związku Radzieckiego wydało dekret zmieniający krymskotatarskie nazwy rejonów i miast rejonowych na rosyjskie. W ten sam sposób w 1945 roku zmieniono nazwy wsi i rad wiejskich (Chazbijewicz 2001b). Po masowym wysiedleniu i ludobójstwie Tatarów krymskich Krym został zasiedlony ludnością rosyjską z obwodów: moskiewskiego, jarosławskiego, penzeńskiego, kurskiego oraz rostowskiego.

Sowiecka akcja deportacyjna z 1944 roku zakończyła etap powstawania i kształtowania się narodu Tatarów krymskich na Krymie. Kolejne lata przyniosły tworzenie się „nowego narodu” mającego świadomość historycznej kontynuacji. Nie wszyscy zesłani pogodzili się ze swoim losem. Wiele osób protestowało i uciekało chcąc dotrzeć do rodzinnych stron. Tatarzy krymscy, jak i inne wysiedlone narody, żyli w nowych miejscach osiedlenia w bardzo ciężkich warunkach, często bez dachu nad głową. Tak np. w regionie kamieńskim na 900 rodzin przypadało 18 mieszkań. Natomiast w obwodzie tałaskim 
116 rodzin żyło pod gołym niebem. Pierwsze formy działań na rzecz zachowania narodowości i walki o powrót pojawiły się po śmierci Józefa Stalina w 1953 roku i słynnym wystąpieniu Nikity Chruszczowa krytykującym „kult jednostki”. Okazją do zademonstrowania nowego klimatu w stosunkach ukraińsko-rosyjskich stała się, przypadająca na 1954 rok, trzechsetna rocznica ugody perejasławskiej. Moskwa wystąpiła wówczas z imponującym „podarunkiem”: przyłączyła do Ukraińskiej Socjalistycznej Republiki Radzieckiej Półwysep Krymski. Była to bez wątpienia racjonalna w ówczesnej rzeczywistości decyzja motywowana względami gospodarczymi i społecznymi. Wydarzenie to uległo mitologizacji, bowiem okazało się, że tego rodzaju gest skuteczniej osłabił ukraińską zdolność do stawiania oporu aniżeli polityka represji (Gibas-Krzak 2006: 33). W 1958 roku przeprowadzono reformę oświaty, która spowodowała dalszą rusyfikację szkolnictwa. Jednocześnie poprawił się poziom życia. Wzrosły płace, polepszyło się zaopatrzenie, w życiu codziennym dawały o sobie znać dobrodziejstwa cywilizacyjne. Generalnie jednak obietnice stworzenia innego świata pozostawały na papierze.

W latach 50. wśród deportowanej ludności zawiązywały się samorzutnie pierwsze kółka samokształceniowe. W głównej mierze zajmowały się szerzeniem kultury i języka tatarskiego. Pierwsze grupy inicjatywne złożone $\mathrm{z}$ tatarskich komunistów o nacjonalistycznym rodowodzie rozpoczęły systematyczną walkę o powrót i ratowanie narodu w 1953 roku. W 1957 roku funkcjonariusze KGB spotęgowali prowokacje przeciwko jednemu z najaktywniejszych działaczy ruchu narodowego krymskich Tatarów - Mustafie Dżemilewowi. Zarzucono mu m.in. udział w Związku Młodzieży Krymskotatarskiej, uczestnictwo w nacjonalistycznych wiecach krymskich Tatarów, a także napisanie książki, w której podkreślał problemy dotyczące nacjonalizmu, wbrew linii partii. W rezultacie M. Dżemilew został uznany za winnego i skazany na półtora roku więzienia.

Rok 1967 stanowi ważną datę we współczesnej historii krymskich Tatarów. Uchwała Prezydium Rady Najwyższej ZSRR „O obywatelach narodowości tatarskiej, byłych mieszkańcach Krymu” i decyzja „O trybie wykonawczym artykułu 2 Uchwały Prezydium Rady Najwyższej ZSRR z 28 kwietnia 1956 roku”, mimo istniejących niedociągnięć, przyjęte zostały przez krymskich Tatarów jako długo oczekiwana rehabilitacja i, co najistotniejsze, jako uprawnienie do powrotu na Krym. Jak pisze S. Chazbijewicz: „(...) stanowi to bowiem cezurę powolnego, acz systematycznego powrotu, który pod koniec lat 60 . był jeszcze niewielkim strumieniem, by przybrać na sile w latach 70., zintensyfikować się w latach 80. i zamienić się w rwącą rzekę w latach 90." (Chazbijewicz 2001a: 149). Lata 60. i 70. to najcięższy okres walki obywatelskiej o prawa narodowe ludności krymskotatarskiej. Lata 70. stanowią cezurę w dziejach ruchu krymskotatarskiego. Od 1989 roku rozpoczęto odbudowę społeczeństwa Tatarów krymskich. Powrót na Krym umożliwił rozpad Związku Radzieckiego i narodziny nowej geopolitycznej przestrzeni. Powracający do ojczyzny napotykali warunki gorsze aniżeli w Azji Środkowej. Ich głównym zadaniem było podjęcie politycznej walki o zapewnienie sobie bytu na Krymie i przeciwstawienie się fali środkowoazjatyckiego nacjonalizmu rodzącego się od lat 70 .

Statystycznie największe nasilenie repatriacji przypadło na lata 1990-1992. W następnych latach liczba powracających na Krym zaczęła znacznie maleć. W 1991 roku przeprowadzone zostało ogólnoradzieckie referendum w sprawie przyszłości państwa. Wówczas za utrzymaniem ZSRR wypowiedziało się na Ukrainie 70 proc. głosujących przy 80 proc. frekwencji. W sierpniu 1991 roku ogłoszono Akt Niepodległości Ukrainy, natomiast władze Krymu rozpisały referendum, w którym 93 proc. głosujących opowiedziało się 
za reaktywowaniem Krymskiej Republiki Autonomicznej w ramach RFSRR. Działania te rozpoczęły konflikt rosyjsko-ukraiński o Krym. W dniu 12 lutego 1991 roku na plenarnym posiedzeniu Rady Najwyższej ZSRR ustanowiono Krymską Autonomiczną Radziecką Republikę Socjalistyczną, która istniała do ósmego grudnia 1991 roku (rozwiązanie ZSRR w Białowieży). Deklaracja suwerenności Republiki Rosyjskiej ogłoszona została 12 czerwca 1990 roku, natomiast 24 września 1991 roku Rada Najwyższa Republiki Krymskiej ogłosiła niepodległość półwyspu. Wówczas rozpoczęła się walka polityczna. Z jednej strony była to rywalizacja rosyjsko-ukraińska, z drugiej - krymscy Tatarzy próbowali przeciwstawić się próbom oderwania Krymu od Ukrainy. Pierwsza sesja Rady Najwyższej odbyła się 22 marca 1991 roku; zaaprobowano wówczas i przyjęto projekt konstytucji. W grudniu 1991 roku Medżlis wysunął własny projekt konstytucji z preambułą „My naród Krymu krymscy Tatarzy (...)”. W treści konstytucji potraktowano krymskich Tatarów, Karaimów i Krymczaków jako jeden naród Krymu. Jak słusznie podkreśla S. Chazbijewicz, ostatecznie wiele artykułów tej konstytucji stało w sprzeczności z ukraińskim prawem „O statusie autonomicznej Republiki Krymu".

Formy samorządu tatarskiego w głównej mierze wynikały z tradycji oraz z konieczności organizacji życia społecznego i politycznego po repatriacji. Wówczas zwołano II Kurułtaj, który nawiązywał do starej mongolsko-tureckiej tradycji. Kurułtaj to rada chanów mongolskich zbierająca się do odbycia narad politycznych lub wyboru nowego wielkiego chana. I Kurułtaj krymskich Tatarów miał miejsce w 1917 roku w pałacu chanów w Bachczysaraju. W XX wieku przyrównywano Kurułtaj do formy narodowego (niepaństwowego) parlamentu, natomiast wyłoniony z Kurułtaju Medżlis - do Rady Narodowej z prerogatywami wykonawczymi. Spotkanie komitetu ds. organizacji Kurułtaju odbyło się 23 września 1990 roku. W komitecie tym znalazło się wówczas 36 osób. Na przewodniczącego powołano Serwera Omerowa, który cieszył się wśród krymskich Tatarów dużym autorytetem. Powołano także Centralną Komisję Wyborczą, Biuro Organizacyjne oraz Komisję Redakcyjną. Wybory były dwustopniowe. W miejscach zamieszkanych przez krymskich Tatarów wybierano elektorów, którzy na konferencjach obwodowych, rejonowych, miejskich czy republikańskich (w zależności od gęstości zaludnienia) wybierali spośród siebie delegatów na Kurułtaj. Czynne i bierne prawo wyborcze posiadali krymscy Tatarzy obojga płci, którzy w dniu wyborów ukończyli 16 rok życia. Wybrano wówczas na Krymie 129 delegatów. Wybrani delegaci wybrali Medżlis liczący 33 osoby. Przewodniczącym Medżlisu został wspomniany Mustafa Dżemilew. Pierwsze spotkanie Medżlisu odbyło się w lipcu 1991 roku. Zatwierdzono na nim strukturę organizacyjną. W przeciągu dwóch lat, tj. 1991-1993, Medżlis odbył 15 posiedzeń zwyczajnych i jedno nadzwyczajne. Posiedzenie nadzwyczajne podyktowane było wydarzeniami z 20 sierpnia 1991 roku - puczem moskiewskim (Chazbijewicz 2001a: 204-207).

Po 1995 roku sytuacja polityczna krymskich Tatarów, w tym krymskotatarskiego ruchu narodowego, w znacznym stopniu uległa zmianie. W styczniu 1995 roku partia Adelt opublikowała protest przeciwko dążeniu władz do legalizacji Krymskiego Kozactwa. W styczniu Rada Najwyższa Krymu przyjęła także uchwałę „O wyborach deputatów i przedstawicieli wiejskich, osiedlowych, rejonowych i miejskich rad". W uchwale mowa była o przedstawicielach deportowanych, w tym: krymskich Tatarów, Greków czy Ormian powracających na Krym w 1995 roku. Ruch krymskotatarski szukał także oparcia ze strony Turcji. Przewodniczący Medżlisu, Mustafa Dżemilew, udał się do Turcji 29 stycznia 1995 roku. Od 
1997 roku nasilała się opozycja względem Mustafy Dżemilewa. Była to opozycja personalna z jednej strony, z drugiej - niechęć do programu współpracy z radziecką demokratyczną opozycją. Wśród tatarskiego społeczeństwa było wielu zwolenników ZSRR.

Poza nielicznymi wyjątkami, język, tradycje i kultura ukraińska zawsze były dyskryminowane w państwie rosyjskim. Najlepszym tego dowodem była konieczność przyjęcia wielu aktów prawnych chroniących język i kulturę ukraińską u schyłku Związku Radzieckiego. Dlatego uważa się, że szczególnie na Krymie, a także we wschodniej i południowej Ukrainie, to nie Rosjanie, a Ukraińcy są mniejszością. Jak słusznie zauważa Walenty Baluk, sami Rosjanie bronią się przed określaniem ich jako mniejszości narodowej (Baluk 2002). W okresie Rosji carskiej czy Związku Radzieckiego etniczni Rosjanie kwantytatywnie zawsze byli mniejszością, natomiast moralnie - większością. Ukraina była więc dla nich jedynie częścią imperium rosyjskiego, z którym się utożsamiali. Dlatego też w sytuacji uzyskania przez Ukrainę niepodległości i suwerenności w 1991 roku, narodził się problem zagrożenia pozycji dominującej, jaką miała dotąd ludność rosyjska. Dla wielu Rosjan zamieszkujących Autonomiczną Republikę Krymu sam fakt konieczności nauczenia się języka ukraińskiego i posługiwania się nim w pracy był formą dyskryminacji. W wielkich miastach wschodu i południa Ukrainy rozmawia się wyłącznie w języku rosyjskim. W czasach Związku Radzieckiego język ukraiński praktycznie wyrugowano. Posługiwanie się nim uznawane było za przejaw burżuazyjnego nacjonalizmu. Sprowadzona do poziomu kołchozowego ukraińska kultura miała opisywać życie skolektywizowanej wsi. Stąd po ogłoszeniu przez Ukrainę niepodległości językowi ukraińskiemu nadano status języka narodowego. Problem językowy, podobnie jak kwestie historyczne czy kulturowe, były paliwem politycznym. Jako pierwszy na problem konieczności zalegalizowania języka rosyjskiego na wschodzie i południu kraju zwrócił uwagę Leonid Kuczma. Kandydując w 1994 roku na stanowisko prezydenta, domagał się nadania językowi rosyjskiemu rangi drugiego języka państwowego. Postulatu tego nie udało mu się zrealizować, mimo iż starał się kluczyć między żądaniami mieszkańców wschodu i zachodu Ukrainy. Sytuacja gwałtownie zmieniła się po Pomarańczowej Rewolucji, gdy nowo powołane władze zaczęły wprowadzać zasadę pozytywnej dyskryminacji - wspierania języka ukraińskiego i ukraińskiej kultury. Wywołało to znaczny opór na wschodzie i południu kraju i tym samym wzmocniło pozycję Partii Regionów Wiktora Janukowycza. Po zwycięstwie tej partii w 2010 roku przyjęto ustawę o językach regionalnych, a jej likwidację w wyniku lutowych wydarzeń 2014 roku uznano za zagrożenie praw i wolności Rosjan oraz ludności rosyjskojęzycznej na Ukrainie (Czech 2014: 1). Stan ten spowodował nasilenie się nastrojów nacjonalistycznych oraz zaowocował niedemokratycznymi posunięciami władz autonomii wobec Tatarów krymskich i Ukraińców. W Autonomicznej Republice Krymu język rosyjski jako ojczysty deklarowało 72,6 proc. mieszkańców, natomiast w obwodzie donieckim - 71 proc. Język rosyjski odgrywa również ważną rolę w obwodach: ługańskim, charkowskim i odeskim (Szeptycki 2013: 245).

Oliwy do krymskiego ognia wciąż dolewała Moskwa, bowiem 24 lutego 2014 roku nacjonalista Władimir Żyrinowski na posiedzeniu rosyjskiej Dumy Państwowej domagał się, by wszystkim mieszkańcom Ukrainy w trybie uproszczonym nadać obywatelstwo Federacji Rosyjskiej. Podobny „chwyt” Kreml zastosował w niedalekiej przeszłości w Gruzji. Wtedy Rosja z rozmachem rozdawała paszporty mieszkańcom gruzińskich prowincji Abchazja i Osetia Południowa (Radziwinowicz 2014). W wyniku lutowych/marcowych wydarzeń 2014 roku na Ukrainie ekstremistyczne kręgi prorosyjskie zmieniły dyskusję o Krymie 
w otwarty konflikt zbrojny między Rosją i Ukrainą. Konsekwencją jest utrata przez Ukrainę Krymu, ale także może nią być utrata innych wschodnich obwodów. Kiedy w Kijowie ukraińskie władze przystąpiły do porządkowania państwa, krok po kroku zdobywając przychylność większości demokratycznego świata, na wschodzie i południu kraju dominuje perspektywa działań wojennych. Z jednej strony zdobyty drogą referendum przez Rosję Krym, z drugiej - niebezpieczny i krwawy Donieck. Gdy na półwyspie 16 marca 2014 roku trwało referendum, w wielu miastach wschodniej Ukrainy odbywały się prorosyjskie demonstracje. Domagano się nie tylko ustąpienia władz w Kijowie, ale także przeprowadzenia we wschodnich regionach referendów dotyczących zmiany konstytucji i przekształcenia Ukrainy w państwo federalne. Michaił Małyszew - szef komisji Rady Najwyższej Krymu ds. Referendum, 17 marca 2014 roku oświadczył, że 95,5 proc. uczestników głosowania opowiedziało się za przyłączeniem Krymu do Federacji Rosyjskiej. Frekwencja wyniosła 81,36 proc. Jak podkreśla Mustafa Dżemilew, 99 proc. ludności tatarskiej nie uczestniczyło w głosowaniu, z kolei jedna czwarta mieszkańców to Ukraińcy, z których nie wszyscy głosowali tak, jak etniczna rosyjska większość (Soszyn 2014c). Tatarzy krymscy uważają, że referendum nie było demokratyczne, ponieważ na terytorium Krymu znajdowało się wówczas 30 tys. rosyjskich żołnierzy. Nie uwierzyli również w obietnice premiera Krymu - Siergieja Aksjonowa, który w konsekwencji marcowych wydarzeń zaoferował Tatarom stanowisko wicepremiera Krymu, dwa ministerialne miejsca w rządzie, stanowiska we wszystkich pozostałych resortach i strukturach siłowych, a także coroczną pomoc krymskotatarskim repatriantom w wysokości 22 mln USD (Soszyn 2014b).

Krymscy Tatarzy są bez wątpienia społecznością pogranicza z racji położenia ich miejsca zamieszkania między Rosją a Ukrainą. Jak podkreśla w swoich rozważaniach Marta Studenna-Skrukwa, rzeczywistą lub postulowaną formą politycznej organizacji narodu jest państwo i to ono, bez względu na swoją genezę, powoduje wytwarzanie się więzi lojalności zamieszkujących je obywateli (Studenna-Skrukwa 2014: 35). Kiedy 16 marca 2014 roku odbyło się ogólnokrymskie referendum, na podstawie którego 18 marca 2014 roku podpisano w Moskwie „Porozumienie między Federacją Rosyjską i Republiką Krym o przyjęciu do Federacji Rosyjskiej Republiki Krym i utworzeniu w składzie Federacji Rosyjskiej nowych podmiotów”, szczególne napięcie w społeczeństwie krymskim wzbudziły organizacje paramilitarne m.in. „Krymscy Strażnicy” czy „oddziały samoobrony” uzupełnione przybyłymi na Krym Kozakami z przygranicznych rejonów Federacji Rosyjskiej oraz Narodowa Partia Tatarska Milli Firka. Napięcia międzyetniczne na Krymie mają miejsce z jednej strony między Rosjanami a krymskimi Tatarami oraz Ukraińcami - z drugiej. W historii niepodległej Ukrainy nie odnotowano znacznych konfliktów pomiędzy Ukraińcami i krymskimi Tatarami, ale z różną intensywnością można było zauważyć nieprzyjazną atmosferę ze strony Rosjan wobec krymskich Tatarów (Voytyuk 2013: 131-132).

Według definicji Antoniny Kłoskowskiej, pogranicze to „obszar stykających się państw, których granica częściowo rozdziela różne grupy etniczne i narodowe, ale nie jest ona granicą nieprzenikalną" (Kłoskowska 1994: 102). Jednakże należy podkreślić, że granice polityczne to nie tylko abstrakcyjne linie na mapie, ale także brzemienne w skutki zmiany ludzkich losów, w tym krymskich Tatarów, którzy nie chcieli przynależeć do Federacji Rosyjskiej. W dniu 11 czerwca 2014 roku Parlament Tatarów - Medżlis - zwrócił się z prośbą do Organizacji Narodów Zjednoczonych oraz OBWE o przysłanie obserwatorów na Półwysep Krymski. Powodem prośby jest stale pogarszająca się sytuacja krymskich Tatarów na zajętym przez Rosję półwyspie. W swoim apelu przedstawiciele Medżlisu 
przedstawiają konkretne przypadki używania przemocy względem tatarskiej społeczności zarówno przez rosyjskie władze okupowanego terytorium, jak i Rosjan zamieszkujących półwysep (,Dramatyczny’ 2014).

\section{Granica ukraińsko-rosyjska}

Po rozpadzie Związku Radzieckiego przez długi czas Rosja odmawiała formalnego potwierdzenia granicy między Federacją Rosyjską a Ukrainą. Głównym powodem był brak jej akceptacji ze strony rosyjskich elit, ponieważ uznały one, że obecna Ukraina obejmuje ziemie, które nigdy do niej nie należały, w tym Krym i Donbas. Stanowiło to element nacisku w kwestii stacjonowania Floty Czarnomorskiej. Nie bez znaczenia są także interesy ekonomiczne obu państw dotyczące przebiegu wspólnej granicy na Morzu Azowskim i w Cieśninie Kerczeńskiej.

W maju 1992 roku rosyjscy deputowani domagali się uregulowania kwestii Krymu na drodze dwustronnych rozmów. Rosja wspierała wówczas krymskich separatystów dążących w latach 90-tych XX wieku do uzyskania autonomii na półwyspie i oderwania się od Ukrainy. W kwestii Sewastopola, rosyjscy deputowani podkreślali wielokrotnie jego historyczną - rosyjską tożsamość, jako bazy rosyjskiej floty. Wykazywali także, że w czasach Związku Radzieckiego Sewastopol był odrębną jednostką administracyjną, a zatem decyzja o przekazaniu Ukrainie Krymu, nie objęła Sewastopola. W 1993 roku Parlament Federacji Rosyjskiej przyjął dokument, który potwierdził „rosyjski, federalny” status Sewastopola, co nie wzbudziło jednak entuzjazmu prezydenta Jelcyna. Postanowienie skrytykowali także przedstawiciele Rady Bezpieczeństwa Organizacji Narodów Zjednoczonych, uznając dekret za sprzeczny z traktatem rosyjsko-ukraińskim z 1990 roku. Traktat o przyjaźni, partnerstwie i współpracy pomiędzy Ukrainą a Federacją Rosyjską potwierdzający nienaruszalność ich wspólnej granicy podpisano dopiero w 1997 roku podczas pierwszej wizyty prezydenta Jelcyna na Ukrainie (Szeptycki 2013: 247).

Ważną częścią granicy między Rosją i Ukrainą jest granica morska. Szczególnie chodzi tu o odcinek biegnący przez Morze Azowskie i Cieśninę Kerczeńską. Znaczenie tego regionu bezsprzecznie wynika z bogatego potencjału gospodarczego (surowce energetyczne, zasoby ryb) oraz geostrategicznego - Morze Azowskie oraz Cieśnina Kerczeńska to jedyna droga morska łącząca Rosję południowo-zachodnią z oceanem. Średnio przepływa przez nią około 9 tys. statków rocznie. Istota sporu między Federacją Rosyjską a Ukrainą leży w kwestii wyspy Tuzła, będącej „częścią” Półwyspu Tamańskiego, leżącego po wschodniej stronie cieśniny. Historycznie - w 1941 roku - wyspa została podporządkowana władzom administracyjnym Kerczu, jednakże w 1954 roku wraz z całym Półwyspem Krymskim została przekazana Ukraińskiej Socjalistycznej Republice Radzieckiej. Problem przynależności wyspy nabrał znaczenia po rozpadzie Związku Radzieckiego w 1991 roku. Jedyny szlak komunikacyjny Cieśniną Kerczeńską przebiega między wyspą Tuzła i wybrzeżem Krymu, dlatego Ukraina uznała, że są to wody ukraińskie. Natomiast Rosja decyzję z 1941 roku przyjęła za bezprawną, a wyspę traktowała jako przedłużenie mierzei. Do kryzysu między Federacją Rosyjską a Ukrainą w sprawie Cieśniny Kerczeńskiej doszło w 2003 roku. Wówczas Rosja zdecydowała się wybudować w cieśninie groblę, łączącą Półwysep Tamański z wyspą Tuzłą. Decyzje rosyjskie ostro skrytykował Leonid Kuczma oraz Rada Najwyższa, zarzucając Rosji imperializm. Ostatecznie budowę grobli wstrzymano zanim dotarła do granicy Ukrainy. W 2003 roku podpisano umowę o współpracy w wykorzystaniu Morza Azowskiego i cieśniny między dwoma państwami, nazywając je „historycznymi wodami wewnętrznymi”. Umowa 
nie nakładała ograniczeń w ruchu statków i okrętów wojennych Ukrainy i Rosji oraz statków państw trzecich. Uzależniała jednak obecność okrętów wojennych innych państw od zgody obu państw. Wiązało się to wówczas z zagrożeniem, że Rosja może uniemożliwić wpłynięcie na Morze Azowskie okrętów państw Sojuszu Północnoatlantyckiego w razie wspólnych manewrów Ukraina-NATO. W 2012 roku Władimir Putin oraz Wiktor Janukowycz podpisali wspólne oświadczenie w sprawie delimitacji granicy morskiej. Potwierdzono przynależność wyspy Tuzła do Ukrainy, natomiast Rosja zachowała prawo do korzystania z Cieśniny Kerczeńskiej (Szeptycki 2013: 242-251).

Pomimo istnienia w stosunkach narodowościowych na Krymie wielu punktów zapalnych, największym problemem etniczno-terytorialnym, a także gospodarczym pozostają wciąż 380-tysięczny Sewastopol oraz 150-tysięczny przemysłowy Kercz, który od Rosji dzieli jedynie kilkusetmetrowa cieśnina. W zatokach krymskich od zakończenia wojny domowej po rewolucję z 1917 roku znajdowały się główne bazy marynarki wojennej, dając Rosji poczucie panowania nad Morzem Czarnym. Federacja Rosyjska, zachowując możliwość kontrolowania sytuacji na Ukrainie poprzez stacjonowanie na półwyspie potężnych sił wojskowych, mogła śledzić sytuację na całej długości granicy rosyjsko-ukraińskiej. Historia Floty Czarnomorskiej sięga 1783 roku. Sewastopol - główna jej baza - była dwukrotnie oblegana przez siły francusko-brytyjskie podczas wojny krymskiej w 1853-1856 roku oraz przez Niemców podczas II wojny światowej. Dzięki temu w Związku Radzieckim miasto zyskało tytuł: miasta-bohatera „Miasta Rosyjskiej Sławy”.

Po 1945 roku Flota Czarnomorska była nie tylko instrumentem służącym utrzymaniu wpływów w regionie, ale także zapewniała obecność militarną Związku Radzieckiego w basenie Morza Śródziemnego, gdzie stanowiła przeciwwagę dla amerykańskiej IV Floty (Szeptycki 2013: 230). Flota Czarnomorska odgrywa istotną rolę w polityce Rosji. Region czarnomorski jest dla tego kraju ważny przede wszystkim z perspektywy chęci utrzymania wpływów w poradzieckich państwach basenu Morza Czarnego, a także z potrzeby wsparcia separatystycznego Naddniestrza oraz Abchazji i Osetii Południowej. Duże znaczenie ma również dla tranzytu surowców energetycznych z basenu Morza Kaspijskiego do Europy. Na początku XX wieku Flota Czarnomorska dawała pracę około 100 tys. mieszkańców Sewastopola. Ponadto, ze stacjonowania Floty Czarnomorskiej pochodziło 15 proc. dochodów budżetu miasta. Kwestia podziału floty między Rosję i Ukrainę rozwiązana została w 1997 roku. Wówczas podpisano traktat dwustronny: trzy umowy dotyczące podziału rosyjskiej Floty Czarnomorskiej, w których określono zasady stacjonowania floty na terytorium Ukrainy oraz wzajemnych rozliczeń. Po wyborach w 2010 roku polityka Ukrainy względem Floty Czarnomorskiej uległa zasadniczej zmianie. W kwietniu 2010 roku prezydenci Wiktor Janukowycz oraz Dmitrij Miedwiediew podpisali porozumienie charkowskie, na podstawie którego przedłużono okres stacjonowania Floty Czarnomorskiej na Ukrainie o 25 lat (do 2042 roku) z możliwością prolongaty o kolejne pięć lat. Obecność Floty Czarnomorskiej bez wątpienia ograniczała niezależność Ukrainy, stanowiąc jednocześnie dla Rosji instrument nacisku (Szeptycki 2013: 231-241).

W aspekcie gospodarczym Rosja była największym inwestorem w Autonomicznej Republice Krymu. Ważną dziedzinę stanowiła dwustronna współpraca w sferze turystyki, skoncentrowana wzdłuż wybrzeża Morza Czarnego oraz Azowskiego, ale także w Górach Krymskich. Ogromną rolę Rosja odgrywała także w przestrzeni kulturowo-informacyjnej oraz edukacyjnej. Rosyjskojęzyczne media systematycznie wypierały ukraińskie, 
podnosząc kwestię statusu Krymu i przekonując mieszkańców o jego tymczasowej przynależności do Ukrainy. W Sewastopolu istniały np. trzy filie rosyjskich uniwersytetów, m.in.: Moskiewskiego Państwowego Uniwersytetu (Szeptycki 2007: 180-190).

\section{Zakończenie}

Południowo-wschodnia część Ukrainy jest punktem zapalnym i stanowi trudny do rozwiązania problem $w$ relacjach ukraińsko-rosyjskich. Sytuacja ta bez wątpienia wynika $z$ dążenia do rewindykacji terytorialnych części rosyjskiej klasy politycznej, kwestii związanych ze stacjonowaniem Floty Czarnomorskiej w Sewastopolu oraz separatystycznych dążeń zamieszkałych tam Rosjan. Są to regiony Ukrainy, których rosyjscy mieszkańcy prezentują bliższe związki z Rosją, niż z Unią Europejską. Słusznie zauważa Andrew Wilson, że Ukraińcy i przedstawiciele innych nacji powinni zachować własną, odrębną tożsamość. Bezsprzecznie Rosjanie i Ukraińcy są dwoma członami jednego społeczeństwa ukraińskiego i tak powinno pozostać. Rosjanie na Ukrainie nie chcą być nazywani „mniejszością narodową”. Ukraina jest państwem suwerennym, ale stanie się państwem wolnym od obciążeń i w pełni wolnym kulturowo, gdy uda jej się przezwyciężyć mit imperium, który wciąż jeszcze zniekształca przestrzeń narodową od wewnątrz (Wilson 2002: 220-223). Ukraina na pograniczu dwóch światów to bardzo niebezpieczna koncepcja, ponieważ ten, kto znajduje się "pomiędzy”, nie ma świata własnego. Na Ukrainie duży odsetek Rosjan wciąż wywiera przemożny wpływ na jej tożsamość i kulturę. Postrzegając ukraińskich Rosjan wyłącznie jako kolonizatorów czy też piątą kolumnę, można stracić z oczu całą różnorodność możliwości statusu Rosjanina na Ukrainie. Rosjanom zamieszkującym na wschodzie bliższa jest raczej tożsamość ludzi sowieckich. Setki lat sąsiedztwa sprawiły, że na tych ziemiach trudno odróżnić Ukraińca od Rosjanina. Kultura sowiecka ciągle jest traktowana jako zjawisko umożliwiające swobodne przekraczanie zarówno granic etnicznych, jak i językowych. Póki co, Rosjanie ukraińscy zamieszkujący południowo-wschodnie regiony Ukrainy skłaniają się raczej ku wschodniej wersji własnej tożsamości i nie wygląda na to, by zdolni byli postrzegać się jako Ukraińcy. Wśród nich przeważa pogląd, że wędrują raczej granice a nie oni sami. Stąd też pytanie: czy granica przesunie się dalej? (Riabczuk 2004: 18). Wszystko wskazuje na to, że tak. Po referendum na Krymie, mieszkańcy Doniecka również się go domagają. Podobnie sytuacja wygląda w całym regionie Donbasu. Rozbrzmiewają min. hasła: ”Jeden Donbas”, „Donbas-Rosja”. W Charkowie 17 marca 2014 roku zebrało się około trzech tysięcy demonstrantów, mimo sądowego zakazu manifestacji. Społeczeństwo południowo-wschodniej części Ukrainy domaga się zmiany konstytucji i federalizacji kraju. Od 16 marca w ręce mieszkańców południowowschodnich regionów trafiały ulotki, na których umieszczono trzy pytania: 1. Czy jesteś za federalizmem, to znaczy za tym, aby lokalne władze dysponowały środkami tam wypracowanymi? 2. Czy jesteś za władzą ludu nie tylko w okresie wyborczym? 3. Czy jesteś za suwerennością językową? Nie ma wątpliwości, że Moskwa prowadzi kampanię na rzecz przekształcenia Ukrainy w państwo federalne, pragnąc zachować w nim swoje wpływy. Władimir Sidenko - szef kijowskiego Centrum Razumkowa uważa, że „federalizm prowadzi nie tylko do niezależności finansowej, ale co ważniejsze do zapewnienia obecnym elitom władzy we wschodnich regionach kraju" (Jendroszczyk 2014a). W tej sytuacji ukraińskim władzom nie pozostaje nic innego, jak pójść drogą Gruzji. Parlament Ukrainy powinien przyjąć uchwałę o okupacji Ukrainy przez Federację 
Rosyjską. Ustawa o terenie okupowanym pozwoliłaby Ukraińcom określić zasady prowadzenia działalności gospodarczej na terenach południowo-wschodnich. Problem pojawia się w przypadku prawa, bowiem żadna z inwestycji nie byłaby uznawana przez władze ukraińskie.

\section{Literatura:}

Baluk, W. (2002). Koncepcje polityki narodowościowej Ukrainy. Tradycje, współczesność. Wrocław: Uniwersytet Wrocławski.

Chazbijewicz, S. (2001a). Adwet czyli powrót. Walka polityczna Tatarów krymskich o zachowanie tożsamości narodowej i niepodległość państwa po II wojnie Światowej. Olsztyn: Uniwersytet Warmińsko-mazurski.

Chazbijewicz, S. (2001b). Tatarzy krymscy. Walka o naród i wolną ojczyznę. PoznańWrześnia: Likon.

Czech, M. (2014). Parlament rządzi, Majdan czuwa. Gazeta Wyborcza, nr 45.

,Dramatyczny'. (2014). Dramatyczny apel parlamentu Tatarów: porywają naszych rodaków na Krymie. Pobrano 14.11.2014, z: http://wiadomosci.wp.pl/lbid,7822,title,MustafaDzemilew-Tatarzy-nie-poszli-na-wspolprace-z-Rosja,nazywo.html?ticaid=112eda.

Jendroszczyk, P. (2014a). Krym stracony dla Ukrainy. Rzeczpospolita, $n r 70$.

Jendroszczyk, P. (2014b). Scenariusz dla wschodniej Ukrainy. Rzeczpospolita, nr 63.

Kirimal, E. (1995). Eksterminacja Tatarów Krymskich. Rocznik Tatarów Polskich, t. III.

Kłoskowska, A. (1994). Pogranicze kulturowe w perspektywie badań biograficznych.

W: W. Władyka (red. nauk), Inni wśród swoich. Warszawa: Instytut Badań Literackich PAN.

Podhordecki, L. (1987). Chanat Krymski i jego stosunki z Polską w XV-XVIII $w$.

Warszawa: Bellona.

Radziwinowicz, W. (2014). Majdan wybiera rząd, na Krymie wrze. Gazeta Wyborcza, nr 48.

Riabczuk, M. (2004). Dwie Ukrainy. Wrocław: Kolegium Europy Wschodniej.

Soszyn, R. (2014a). Jeden krok do podziału Ukrainy. Rzeczpospolita, nr 45.

Soszyn, R. (2014b). Czy Moskwa przekupi Tatarów?. Rzeczpospolita, nr 61.

Soszyn, R. (2014c). Krym odchodzi do Rosji. Rzeczpospolita, nr 63.

Studenna-Skrukwa, M. (2014). Ukraiński Donbas, oblicza tożsamości regionalnej. Poznań: Wydawnictwo Nauka i Innowacje.

Szeptycki, A. (2007). Ukraina: Panowanie na rozdrożu. Warszawa: Rocznik Strategiczny 2006-2007.

Szeptycki, A. (2013). Ukraina wobec Rosji - Studium zależności. Warszawa: Uniwersytet Warszawski.

„Problemy' (2013). Problemy w wzajemnej tolerancji ludności zamieszkującej

Autonomiczną Republikę Krymu. Pobrano 12.06.2014, z: http://repozytorium.uwb.edu.pl/ jspui/bitstream/11320/694/1/Pogranicze_22_Voytyuk.pdf

Wilson, A. (2002). Ukraińcy. Warszawa: Świat Książki. 